Canadian University Music Review

Revue de musique des universités canadiennes

Robert Donington. Opera and Its Symbols: The Unity of Words, Music and Staging. New Haven: Yale University Press, 1990. viii, 248 pp. ISBN 0-300-04713-4

\title{
Mary Woodside
}

Volume 11, numéro 1, 1991

URI : https://id.erudit.org/iderudit/1014839ar

DOI : https://doi.org/10.7202/1014839ar

Aller au sommaire du numéro

\section{Éditeur(s)}

Canadian University Music Society / Société de musique des universités canadiennes

\section{ISSN}

0710-0353 (imprimé)

2291-2436 (numérique)

Découvrir la revue

Citer ce compte rendu

Woodside, M. (1991). Compte rendu de [Robert Donington. Opera and Its Symbols: The Unity of Words, Music and Staging. New Haven: Yale University Press, 1990. viii, 248 pp. ISBN 0-300-04713-4]. Canadian University Music Review / Revue de musique des universités canadiennes, 11(1), 139-141. https://doi.org/10.7202/1014839ar

All Rights Reserved (C Canadian University Music Society / Société de musique des universités canadiennes, 1991
Ce document est protégé par la loi sur le droit d'auteur. L’utilisation des services d'Érudit (y compris la reproduction) est assujettie à sa politique d'utilisation que vous pouvez consulter en ligne.

https://apropos.erudit.org/fr/usagers/politique-dutilisation/ 
compositeure à succès : La Bolduc. Puis, accédant de plus en plus à une formation musicale sérieuse, les auteures-compositeures participant au « Concours de la chanson canadienne » institué par la Société Radio-Canada (1954-64) où plusieurs d'entre elles se classent parmi les premières.

Avec la montée du nationalisme des années soixante, elles s'impliquent sur le plan politique et leurs chansons reflètent la voix d'un peuple colonisé, en mal de pays, écho de leur propre cri de femmes soumises, en mal de liberté. La chanson écrite au féminin se précise et se raffine : les cadres musicaux s'élargissent, l'orchestration est plus étoffée, les mélodies présentent certaines innovations et empruntent différents styles qui concordent avec les courants commerciaux de l'heure. La femme entre enfin dans l'univers professionel de la musique et on interprète maintenant ses chansons. Le besoin d'écrire, de raconter, amène une recrudescence de parolières ; elles travaillent souvent dans l'ombre mais leur apport à la chanson ne peut être négligé.

De Madeleine de Verchères à Mitsou, Cécile Tremblay-Matte a réussi à «briser ce silence indécent qui enveloppe depuis toujours la création des femmes dans la chanson » et à aller au-delà de l'ancien cliché qui les confinait à un rôle de muse et d'interprète. Nous ne pouvons plus taire l'existence de ces auteures-compositeures ; elles font désormais partie de notre musique et de notre histoire, ainsi que le chante Jacqueline Lemay:

La moitié du monde est une femme

Aujourd'hui enfin elle réclame

Ce qui lui revient et ce qui est son droit

Il est bien fini le règne de l'unique roi

L'autre côté de la terre

Passe à la lumière

La moitié du monde est une femme.

Johanne Hébert

ROBERT DONINGTON. Opera and Its Symbols: The Unity of Words, Music and Staging. New Haven: Yale University Press, 1990. viii, 248 pp. ISBN 0-300-04713-4

Robert Donington meant this book to be the culmination of his extensive work in the field of opera. In many ways it completes the process begun many years before in Wagner's "Ring" and Its Symbols (London, 1983) and The Rise of Opera (New York, 1981). Indeed, the author regards it as a re-consideration of his work in this field and hopes that it will be "in this new presentation, at once contracted and expanded" [Donington 1990: 4] that his contribution will be assessed. Although it would thus seem to be addressed to a scholarly audience, the work is in fact quite readily accessible to the general public - or at least that segment of it which is interested in opera.

One example of expansion is the author's definition of opera itself. In The Rise of Opera, opera was defined as "staged drama unfolding integrally in words and music," [Donington 1981:20] whereas in Opera and Its Symbols, this has been enlarged to include the "unity of words, music and staging." Indeed, the central point of the book is that opera must be presented as a unified whole with its original music, text and staging if listeners are to receive the complete message of the work of art. Only in this way will the symbolism presented in each of the three arts act in complementary fashion. The "enemy" here is the 
stage director who insists on modernizing the production (something he would do to the music only in peril of his life!) "on the misguided assumption that he can give a new freshness to the old conventions[,] ... a mistaken enterprise from the start" [Donington 1990: 12]. Donington objects to the grafting of alien imagery with a totally different message onto a story already complete in itself: Rigoletto as a Mafia tale, the Ring as a Marxist morality play. And indeed, on the proverbial "desert island," given only one possible production of an opera, who would not opt for the original? But we are not as yet - on a desert island, and many of the operas which Donington discusses later in this book are performed often, perhaps too often, to maintain the interest of the knowledgeable opera fan. In this case, I, for one, do not object to some new ideas in staging, second-best as they may be, as a way to freshen the sense of the work, to surprise, to interpret better an image for the modern audience, or to draw a comparison between a character or situation which may illuminate both the opera itself and also a contemporary social situation. What works for one viewer may not, of course, work for another, this being a highly individual matter. Perhaps when an art work leaps continents, for example, it will mean more to a greater proportion of the audience if some of the staging is reinterpreted for that new setting. Perhaps, again, that new staging would be inappropriate if transplanted back to the original scene. I do not think the matter is so simply decided by the caveat, "back to the original." To be fair, though, I find myself often agreeing with Donington's judgement of the productions which he describes, although the reader may sometimes find the superior tone in which these opinions are couched somewhat patronizing. Some modernizations Donington will allow if he feels they do no violence to the original. In other words, he does not reject a change in staging on principle (although we are often made to believe that he does) but only if it is infelicitous.

The second major theme of this book is the application of Jungian archetypes to the stories of many well-known operas. Here, too, there is a connection with the author's previous work. Wagner's "Ring:" and Its Symbols presented just such an analysis of that monumental nineteenth-century work; in at least one review of the 1963 book, the critic (not overly sympathetic to what he called "pseudo-scientific woffle") admitted that this sort of analysis might be possible for Wagner, whose characters are "puppets" anyway, but averred that it would be impossible to apply to the operas of Mozart or Verdi whose characters were real human beings. [Pirie 1963: 354]. Whether Donington ever even read that review I cannot say, but he has quite admirably done the "impossible" by giving insightful analyses of a plethora of operas from Monteverdi through Berg and Britten by pointing out the presence of Jungian archetypes in plots, situations, and characters. He goes further, indeed, to attempt a little psychoanalysis of the composers as well.

Out of the many examples, I choose two which I found illuminating and which lived up to the dust-jacket description of shedding "new light on operatic situations that are problematic or have become over-familiar." The first is the character Don Giovanni whom, although he masquerades as a man of passion, the author perceives to have a "heart of stone," [Donington 1990: 59] just like the Statue which drags him to hell. Donington's description of the Don Juan character is apt and convincing, demonstrating again the keen psychological insight possessed by Da Ponte and Mozart. One need not agree with every element in Donington's interpretation in order to see that the Don is indeed an archetypical character, the understanding of whom may vary from person to person without destroying the timeless truth of the portrait itself. Incidentally, a recent production of Don Giovanni, modernized in a way that probably would not have won Donington's approval, achieved nevertheless a brilliant stroke of imagery by casting identical twins 
as the Don and his valet, Leporello. Although it would have hardly been practical for Mozart to specify this casting, even had he thought of it, the twins in this case do symbolize an idea already native to the plot; that Leporello (and hence everyman) envies the Don and imitates him at every chance.

A second example is Rigoletto, as repulsive a story as is to be found in the operatic literature. Donington identifies a "sweet but sickly odour of incest" [Donington 1990: 86] that explains, for this reviewer at any rate, the disgust one feels at the exploitative nature of the tale. Here the psychological truths are not so much on the individual level as on the situational; the details of this particular story may be highly improbable but the outcome is not: the incestuous father will end up destroying his daughter just as surely as Rigoletto does Gilda.

In general, the insights afforded female operatic characters are less numerous. We may learn that Don Giovanni is a "mother's boy" at heart (an explanation I for one have never found very convincing) but what about his female counterpart in sexual profligacy, Bizet's Carmen? The best we get here is that Carmen demonstrates a clear example of a powerful death wish in choosing not to escape the fate foretold in the cards. But what has caused her to act as she does? The answer is not given.The Queen of the Night, as archetypical "Great Mother" to Tamino as well as Pamina, must be put aside in the course of The Magic Flute because "growing away from mother is part of a man's [sic] normal development" [Donington 1990: 68], but that is an explanation of someone else's psychology, not hers. The archetypical truths to be told in opera are not so much in the correct psychological portraits of the female characters but in the fate afforded them, whether false (Carmen) or true (Butterfly), mother (Queen of the Night) or daughter (Gilda), strong (Dido) or weak (Mimi).

Donington adds, as an appendix, notes to the various chapters which, together with the list of references which follows, amount to an annotated bibliography of an extensive portion of the literature on opera. As with the main body of the text, Donington writes in a very personal style as though the reader is sharing in a stimulating conversation over a glass of sherry and is somehow included in the judgements being made.

Had Donington lived to see his book published, I am sure that he would have corrected a few small deficiencies in its physical layout: the cramped type-face of the italics is not aesthetically pleasing and the captions and brief discussions accompanying the many illustrations are not always sufficiently differentiated from the main body of the text. Otherwise the book is very attractively presented, a fitting format for the last testament of its author.

\section{REFERENCES}

DONINGTON, Robert.

1963: Wagner's “Ring” and Its Symbols. London: Faber \& Faber.

1981: The Rise of Opera. New York: Charles Scribner's Sons.

1990: Opera and Its Symbols: the Unity of Words, Music and Staging. New Haven: Yale University Press.

PIRIE, Peter J.

1963: Review of Wagner's “Ring” and Its Symbols. Music Review vol. 24, 354357.

Mary Woodside 